\title{
Nutrition content assessment of Arachis hypogaea L. samples grown in the Mediterranean region of Turkey
}

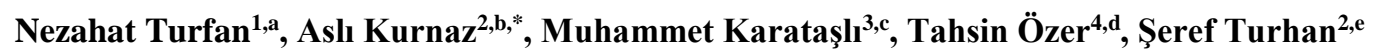 \\ ${ }^{1}$ Department of Biology, Faculty of Science and Letters, Kastamonu University, 37200 Kastamonu, Turkey \\ ${ }^{2}$ Department of Physics, Faculty of Science and Letters, Kastamonu University, 37200 Kastamonu, Turkey \\ ${ }^{3}$ Department of Physics, Faculty of Science and Letters, University of Cukurova, 01380 Adana, Turkey \\ ${ }^{4}$ Bahçe Vocational High School, University of Korkut Ata, 80000 Osmaniye, Turkey \\ *Corresponding author
}

\begin{tabular}{|c|c|}
\hline A R T I C L E I N F O & A B S T R A C T \\
\hline $\begin{array}{l}\text { Received : 21/01/2019 } \\
\text { Accepted : 09/05/2019 }\end{array}$ & $\begin{array}{l}\text { A total of } 42 \text { Turkish peanuts (Arachis hypogaea L.) samples were analysed for their total free amino } \\
\text { acid, } \beta \text {-carotene, lycopene, and flavonoid contents, and the total phenols, glucose, fructose and } \\
\text { sucrose in the peanut samples were determined as nutrition aspects. The average values of the total } \\
\text { free amino acid, beta-carotene, lycopene, glucose, fructose and sucrose were determined to be } 14.4 \\
\mu \mathrm{mol} \mathrm{g}^{-1}, 14.4 \mu \mathrm{g}(100 \mathrm{ml})^{-1}, 14.4 \mu \mathrm{g}(100 \mathrm{ml})^{-1}, 1.07 \mathrm{mg} \mathrm{g}^{-1}, 0.52 \mathrm{mg} \mathrm{g}^{-1} \text { and } 2.74 \mathrm{mg} \mathrm{g}^{-1} \text {, } \\
\text { respectively. The results reveal that the consumption of Turkish peanut samples is safe and that they } \\
\text { contain health-enhancing nutrients. }\end{array}$ \\
\hline
\end{tabular}

Keywords:

Turkish peanuts

Nutrition

Adana

Turkey

Health-enhancing

A total of 42 Turkish peanuts (Arachis hypogaea L.) samples were analysed for their total free amino acid, $\beta$-carotene, lycopene, and flavonoid contents, and the total phenols, glucose, fructose and free amino acid, beta-carotene, lycopene, glucose, fructose and sucrose were determined to be 14.4

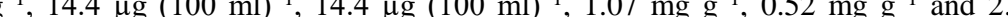

contain health-enhancing nutrients.

\section{Introduction}

Groundnuts (Arachis hypogaea) or peanuts are legumes that are widely cultivated in tropical and subtropical regions of the world. They are economically important due to their high nutrient and oil contents. Peanuts contain 44$56 \%$ oil, $22-30 \%$ protein, $9.5-19.0 \%$ total carbohydrates as both soluble and insoluble carbohydrates and $2.3 \%$ ash on a dry seed basis (USDA National Nutrient Database for Standard Reference, 2010). In addition, they are in rich some minerals such as $\mathrm{P}, \mathrm{Ca}, \mathrm{Mg}$ and $\mathrm{K}$ and antioxidant compounds such as phenols, flavones, essential amino acids, carotenoid and vitamins (E, K, and B group) (Food and Agriculture Organisation of the United Nations, 2010). Peanuts are used as snacks, in oils and soaps and in bakery production and are used as animal feed due to their high protein content (Arığlu, 2013). In addition, as a member of the legume family, peanuts have the ability to provide nitrogen fixation and improve the nutrient levels of soil (Hammond et al., 1992). In this context, peanuts are often used in crop rotation. Peanuts are cultivated on the southern and southwestern coasts of Turkey, especially in Adana and Osmaniye (Çalışkan et al., 2008). A total of $82 \%$ of the planting areas are in the Adana and Osmaniye provinces, and $85 \%$ of peanut production is carried out in these two provinces. While the peanut production area in Turkey is $37 \%, 40 \%$ of the total production amount takes place in the Osmaniye province (İşler and Gözüyeşil, 2016). According to the Provincial Director of Food, Agriculture, and Livestock in Osmaniye, in 2016, 48.573 tonnes of yield were obtained form 126.665 decares and an additional average yield of 341 pounds was gained in the second reported crop. In 2017, the total planting area was 126.140 decares and 47.933 tonnes is expected for the harvest. 
While $40 \%$ of peanut production is performed in Osmaniye, $90 \%$ of all peanuts produced in the country are processed in and marketed to Turkey. The peanut genotypes are the Virginia, Spanish and Valencia genotypes; however, a semi-sloped form of a Virginia origin is mostly grown in Turkey (Akova, 2000). Of these varieties, the NC-7, cultivars are grown due to being early. Results of studies on peanut seeds have shown that they contain polyphenols, which have antioxidant effects. Arıoglu et al. (2013) found that the protein content changed depended on the planting density and that the protein level varied between $26.63 \%$ and $27.62 \%$ in 2013 , between $25.06 \%$ and $29.50 \%$ in 2014 and between $26.02 \%$ and $28.56 \%$ in a two-year average. Nepote et al. (2005) and Chukwumah et al. (2009) found that peanut seeds are rich in phenolic content. Pattee et al. (1981), Xu et al. (2007) and Francisco and Resurreccion (2008) stated that peanuts contain high levels of free amino acids, carbohydrates, and proteins in maturing seeds. Gulluoglu et al. (2016) and Kadiroğlu (2008) stated that the pre/post-harvest conditions and cultivating methods might affect the yield, quality and some agronomic characteristics of peanuts. This study seeks to determine the contents of free amino acids, phenols, flavonoids and sugars such as glucose, fructose, and sucrose in growing peanut samples from various locations in Adana in Turkey Table 1).

\section{Materials and Methods}

\section{Study Area}

Adana is one of the five largest economic, social and cultural centres in Turkey. Its main products are wheat, cotton, corn, soy, and peanuts. It is located on the Seyhan River, which is in Southeast Turkey in the South Central Anatolia region (Fig. 1).

The surface area of the province is approximately 1945 $\mathrm{km}^{2}$, and the mean altitude of the city centre is $23 \mathrm{~m}$. It has a typical Mediterranean climate. The average monthly temperature is $18.9^{\circ} \mathrm{C}$, the warmest month is July at $27.8^{\circ} \mathrm{C}$ and the coolest month on average is January at $9.4^{\circ} \mathrm{C}$. The mean precipitation for a year in Adana is $642.6 \mathrm{~mm}$. Seed samples were collected from different areas and placed in bags (Fig. 1, Table 1). All the analyses were performed using all peanut samples with three replications. Fresh (mature) samples were cut into small pieces and dried in an oven at $60^{\circ} \mathrm{C}$ to a constant weight over approximately 72 h. Then, the dried samples were ground into a fine powder using a laboratory mill. The ground samples were placed in polyethylene bags, labelled, sealed and stored at $4^{\circ} \mathrm{C}$.

\section{Chemical Analyses}

Total free amino acids: The peanut samples $(0.5 \mathrm{~g})$ were boiled in $10 \mathrm{ml}$ of $80 \%$ ethanol. The obtained extract was centrifuged at $800 \mathrm{~g}$ for $15 \mathrm{~min}$. The supernatant was completed to $10 \mathrm{ml}$ with $80 \%$ ethanol. Then, $1 \mathrm{ml}$ of extract was transferred into a test tube $(25 \mathrm{ml})$ and $0.1 \mathrm{~N} \mathrm{NaOH}$ was added using methyl red. A total of $1 \mathrm{ml}$ of ninhydrin reagent was added, and the mixture was boiled for $20 \mathrm{~min}$. Then, $5 \mathrm{ml}$ of ninhydrin reagent was added and the mixture was cooled. The mixture was completed to $25 \mathrm{ml}$ with distilled water. The standard was prepared with glycine, and the absorbance was read at $570 \mathrm{~nm}$ (Moore and Stein, 1948).

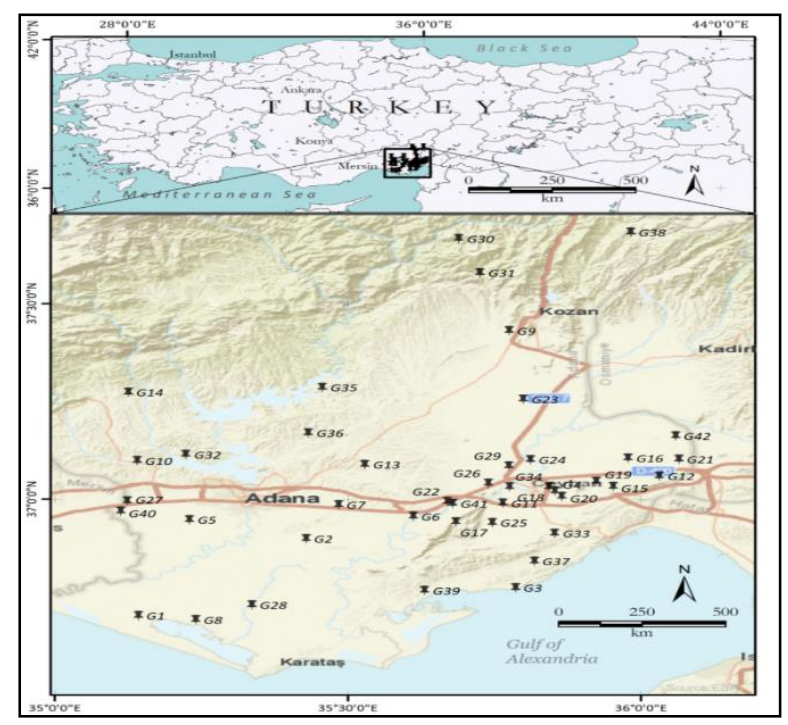

Figue 1 Locations of the sampling sites

Table 1 Peanut cultivars collected from 42 different area

\begin{tabular}{l|l}
\hline Sample code & \multicolumn{1}{|c}{ Location } \\
\hline P1 & Tuzla \\
P2 & Yüreğir \\
P3 & Yumurtalı \\
P4 & Ceyhan \\
P5 & Seyhan \\
P6 & Misis \\
P7 & Kürkçüler \\
P8 & Karataş \\
P9 & Kozan \\
P10 & Çukurova \\
P11 & Tokmaklı \\
P12 & Azizli \\
P13 & Sarıçam \\
P14 & Karisalı \\
P15 & Soğukpınar \\
P16 & Dağıstan \\
P17 & K1zllere \\
P18 & Büyükmangıt \\
P19 & Hamdilli \\
P20 & Değirmendere \\
P21 & Mustafabeyli \\
P22 & Çakaldere Köyü \\
P23 & Camıağ1l Köyü \\
P24 & Hamitbeybucağ1 Köyü \\
P25 & Yeniköynazımbey Köyü \\
P26 & Y1lankale Köyü \\
P27 & Zeytinli Köyü (Seyhan) \\
P28 & Yüzbaş1 Köyü (Karataş) \\
P29 & Küçükmangıt \\
P30 & Velcanlı Köyü (Kozan) \\
P31 & Kuytucak Köyü (Kozan) \\
P32 & Memişlü Köyü (Karisalı) \\
P33 & Narlı Köyü (Ceyhan) \\
P34 & Sarıkeçili Köyü (Ceyhan) \\
P35 & Sayca Köyü (İmamoğlu) \\
P36 & Turunçlu köyü (Kozan) \\
P37 & Sugözü (yumurtalı) \\
P38 & Kuyubeli Köyü (Kozan) \\
P39 & Deveciuşağ1 Köyü (Yumuratlık) \\
P40 & Gökçeler Köyü (Seyhan) \\
\hline
\end{tabular}


Estimation of $\beta$-carotene and lycopene: The $\beta$-carotene and lycopene content of the groundnut samples were determined using the methods given in Nagata and Yamashita (1992). Peanut samples were extracted with acetone-hexane (4:6) at once, then the optical density of the supernatant at $663 \mathrm{~nm}, 645 \mathrm{~nm}, 505 \mathrm{~nm}$, and $453 \mathrm{~nm}$ was measured via a spectrophotometer at the same time. The concentrations of $\beta$-carotene ( $\beta c$ ) and lycopene (Ly) in the groundnut sample extracts (in $\mathrm{mg}$ per $100 \mathrm{ml}$ ) were estimated spectrophotometrically using the following equations (Nagata and Yamata, 1992):

$$
\begin{aligned}
& \beta c=0.216 \times \mathrm{A}_{1}-1.22 \times \mathrm{A}_{2}-0.304 \times \mathrm{A}_{3}+0.452 \times \mathrm{A}_{4} \\
& \text { Where; } \\
& \beta \mathrm{c} \quad=\beta \text {-Carotene in } 100 \mathrm{ml} \\
& \mathrm{A}_{1}=\mathrm{A} 663 ; \mathrm{A}_{2}=\mathrm{A} 645 ; \mathrm{A}_{3}=\mathrm{A} 505 ; \mathrm{A}_{4}=\mathrm{A} 453 \\
& \mathrm{Ly}=-0.0458 \times \mathrm{A}_{1}+0.204 \times \mathrm{A}_{2}+0.372 \times \mathrm{A}_{3}-0.0806 \times \mathrm{A}_{4}
\end{aligned}
$$

Where;

Ly =Lycopene in $100 \mathrm{ml}$

$\mathrm{A}_{1}=\mathrm{A} 663 ; \mathrm{A}_{2}=\mathrm{A} 645 ; \mathrm{A}_{3}=\mathrm{A} 505 ; \mathrm{A}_{4}=\mathrm{A} 453$

Total flavonoids: The flavonoid content was determined in the samples via spectrophotometry. A total of $10 \mathrm{mg}$ of the powdered peanut samples was diluted to 1 $\mathrm{ml}$ via methanol and extracted. Then, $100 \mu \mathrm{l}$ of the extract was mixed with $100 \mu \mathrm{l}$ of $20 \%$ aluminium trichloride $\left(\mathrm{AlCl}_{3}\right)$ and a drop of acetic acid was added to this mixture. The total volume was completed to $5 \mathrm{ml}$ with methanol. After a 40-min incubation at room temperature, the absorbance of the pink colour in the samples was measured spectrophotometrically at $415 \mathrm{~nm}$ and calculated using quercetin as a standard. The results were calculated using a regression equation of the obtained curve and expressed as $\mathrm{mg}$ of quercetin equivalent per $\mathrm{g}$ of powdered peanut sample (Kumaran and Karunakaran, 2006).

Total phenols: The total phenolic content (TPC) was determined using a Folin-Ciocalteu assay (Singleton et al., 1999). A total of $1 \mathrm{~g}$ of the samples was diluted to $1 \mathrm{ml}$ with methanol and extracted. A 2.5-ml Folin-Ciocalteu reagent $(10 \%)$ was added to the extract $(0.5 \mathrm{ml})$ and mixed. Next, $2.5 \mathrm{ml}$ of $7.5 \%$ saturated sodium carbonate solution was added to this mixture. The mixture was incubated at $45^{\circ} \mathrm{C}$ for $45 \mathrm{~min}$ in the dark, and the formation of the blue colour of the samples was observed. After this, the absorbance of the blue colour in the samples was measured at $765 \mathrm{~nm}$. For the total phenolic analysis, a calibration curve was obtained using the gallic acid standard. The TPC was calculated using a regression equation of the obtained curve, and the results were expressed as mg of gallic acid equivalent per g of dry sample.

Total soluble sugar and carbohydrate content: The total soluble sugar and carbohydrate content was determined using the Anthrone method. For this purpose, $1 \mathrm{~g}$ of the powdered samples were placed in a 50-ml volumetric flask to, which $50 \mathrm{ml}$ of $80 \%$ ethanol was added. The mixture was incubated at $4^{\circ} \mathrm{C}$ for $24 \mathrm{~h}$. After incubation, the suspension was filtered through a Whatman No. 4 filter paper and this filtrate was used for the glucose determination. To determine the fructose, the remaining sample residue was incubated again in $30 \mathrm{ml}$ of distilled water at $4^{\circ} \mathrm{C}$ for $24 \mathrm{~h}$. Then, the suspension was filtered through a Whatman No. 4 filter paper and the obtained filtrate was used for the fructose determination. The final residue was incubated in $30 \mathrm{ml}$ of $52 \%$ perchloric acid at $4^{\circ} \mathrm{C}$ for $24 \mathrm{~h}$ and then was filtered through a Whatman No. 4 filter paper; the obtained filtrate was used to determine the sucrose (saccharose) and total soluble carbohydrate content. The contents of the total soluble carbohydrate, glucose, fructose, and sucrose were determined using standard calibration curves of glucose, fructose, and sucrose (Pearson et al., 1976).

\section{Results and Discussion}

In general, all seed types accumulate different concentrations of nutrients in their endosperm, cotyledons and seed coat depending on the genotype and the changeable environmental conditions in the final stages of embryo development. Reserve molecules such as carbohydrates, proteins, and oils play an important role as sources of nutrients for humans and animals, as well as for initial seedling growth (Bewley, 2001; Solanki and Sarangi, 2014). Peanut seeds are rich in nutrients such as protein, fatty acids, flavones, phenols, carotenoid and carbohydrates such as glucose and sucrose, as well as vitamins and some minerals. The amounts of these nutrients may vary with the peanut variety, the soil characteristics, the maturation of the peanuts and the pre and post-harvest conditions; in addition, all these mentioned factors affect the flavour and shelf life of the peanuts (Young et al., 1974; Sanders et al., 1989). Analyses of the variance indicate that there are significant differences $(\mathrm{P}<0.05)$ between the peanut samples in terms of the amount of $\beta$-carotene, lycopene, free amino acid, phenols, flavonoids, glucose, sucrose and total soluble material (Tables 2 and 3).

C-40 tetraterpenoid compound carotenoids are synthesized by all plants and are accumulated in plastids, the chromoplast of flowers, fruits, seeds, and storage roots (Li and Yuan, 2013). They have multiple functions in plants such as in the photoprotection of membrane structures, in the photosynthetic apparatus and in coping with different environmental changes. In addition, they provide the precursors of vitamin A, color and aroma in the flowers and fruits and protect the seeds from deterioration (Moise et al., 2013). There is some evidence that carotenoids have a prevention effect for chronic diseases, protect the eye from photooxidation and reduce several types of cancer (Landrum, 2010). In this study, the lowest contents of $\beta$-carotene ranged from $4.689 \mu \mathrm{g} / \mathrm{g}$ to 9.718 $\mu \mathrm{g} / \mathrm{g}$, moderate levels ranged from $10.517 \mu \mathrm{g} / \mathrm{g}$ to 14.629 $\mu \mathrm{g} / \mathrm{g}$ and the highest values ranged from $15.235 \mu \mathrm{g} / \mathrm{g}$ to $20.204 \mu \mathrm{g} / \mathrm{g}$ (Table 2). The lowest lycopene contents were $10.182-17.452 \mu \mathrm{g} / \mathrm{g}$, moderate levels were $20.180-29.770$ $\mu \mathrm{g} / \mathrm{g}$ and the highest concentrations were 3 the $0.591-2.445$ $\mu \mathrm{g}$ (Table 2). The highest amount of $\beta$-carotene was found in P42; whereas, the highest lycopene level was observed in P39. Conversely, the lowest $\beta$-carotene level was observed in P36 and the lowest lycopene value was observed in P11 and P36 (Table 1). 
Table 2 Changing of $\beta$-carotene, lycopene, total phenols and total free amino acid content in peanut cultivars.

\begin{tabular}{|c|c|c|c|c|c|}
\hline $\mathrm{SC}$ & $\beta$-carotene $\mu \mathrm{g} / \mathrm{g}$ & Lycopene $\mu \mathrm{g} / \mathrm{g}$ & Flavones $\mu \mathrm{g} / \mathrm{g}$ & Total phenols $\mu \mathrm{g} / \mathrm{g}$ & Total Free Amino Acid $\mu \mathrm{g} / \mathrm{g}$ \\
\hline $\mathrm{P} 1$ & $8.742 \pm 0.001$ & $17.452 \pm 0.0001$ & $114 \pm 0.002$ & $1.963 \pm 0.02$ & $7.21 \pm 0.08$ \\
\hline $\mathrm{P} 2$ & $17.265 \pm 0.0001$ & $35.885 \pm 0.0001$ & $135 \pm 0.003$ & $2.224 \pm 0.09$ & $12.04 \pm 0.07$ \\
\hline $\mathrm{P} 3$ & $14.981 \pm 0.0001$ & $31.523 \pm 0.0007$ & $198 \pm 0.003$ & $2.013 \pm 0.04$ & $5.89 \pm 0.04$ \\
\hline $\mathrm{P} 4$ & $16.420 \pm 0.0001$ & $34.563 \pm 0.0001$ & $157 \pm 0.004$ & $2.725 \pm 0.08$ & $8.66 \pm 0.06$ \\
\hline P5 & $13.040 \pm 0.0001$ & $26.543 \pm 0.0001$ & $140 \pm 0.001$ & $2.689 \pm 0.01$ & $8.25 \pm 0.09$ \\
\hline P6 & $14.058 \pm 0.0001$ & $28.166 \pm 0.0001$ & $144 \pm 0.002$ & $5.373 \pm 0.05$ & $18.77 \pm 0.22$ \\
\hline P7 & $17.982 \pm 0.0001$ & $37.196 \pm 0.0001$ & $159 \pm 0.005$ & $5.281 \pm 0.04$ & $14.34 \pm 0.11$ \\
\hline P8 & $18.202 \pm 0.0001$ & $37.340 \pm 0.0001$ & $169 \pm 0.002$ & $7.286 \pm 0.04$ & $7.49 \pm 0.08$ \\
\hline P9 & $9.685 \pm 0.0001$ & $20.180 \pm 0.0001$ & $195 \pm 0.003$ & $7.737 \pm 0.06$ & $14.30 \pm 0.09$ \\
\hline P10 & $10.517 \pm 0.0001$ & $20.889 \pm 0.0002$ & $143 \pm 0.002$ & $4.978 \pm 0.08$ & $11.58 \pm 0.09$ \\
\hline P11 & $5.382 \pm 0.0001$ & $10.180 \pm 0.0001$ & $141 \pm 0.002$ & $6.336 \pm 0.04$ & $26.24 \pm 0.11$ \\
\hline $\mathrm{P} 12$ & $8.193 \pm 0.0001$ & $16.462 \pm 0.0001$ & $208 \pm 0.001$ & $6.315 \pm 0.05$ & $12.99 \pm 0.12$ \\
\hline $\mathrm{P} 13$ & $17.841 \pm 0.0002$ & $36.617 \pm 0.0002$ & $135 \pm 0.002$ & $6.102 \pm 0.05$ & $23.73 \pm 0.20$ \\
\hline P14 & $17.335 \pm 0.0001$ & $36.306 \pm 0.0002$ & $123 \pm 0.002$ & $3.007 \pm 0.12$ & $18.55 \pm 0.08$ \\
\hline P15 & $17.542 \pm 0.0002$ & $34.128 \pm 0.0001$ & $100 \pm 0.001$ & $5.173 \pm 0.05$ & $21.20 \pm 0.26$ \\
\hline P16 & $14.555 \pm 0.0001$ & $30.591 \pm 0.0001$ & $154 \pm 0.002$ & $5.369 \pm 0.06$ & $18.54 \pm 0.17$ \\
\hline P17 & $16.817 \pm 0.0001$ & $35.473 \pm 0.0002$ & $158 \pm 0.003$ & $4.918 \pm 0.05$ & $19.94 \pm 0.08$ \\
\hline P18 & $14.157 \pm 0.0001$ & $29.770 \pm 0.0001$ & $115 \pm 0.004$ & $3.658 \pm 0.03$ & $27.72 \pm 0.06$ \\
\hline P19 & $7.033 \pm 0.0001$ & $14.899 \pm 0.0002$ & $122 \pm 0.002$ & $5.772 \pm 0.10$ & $26.73 \pm 0.22$ \\
\hline $\mathrm{P} 20$ & $16.570 \pm 0.0001$ & $34.487 \pm 0.0001$ & $117 \pm 0.002$ & $5.643 \pm 0.10$ & $17.90 \pm 0.23$ \\
\hline $\mathrm{P} 21$ & $15.235 \pm 0.0001$ & $26.535 \pm 0.0002$ & $194 \pm 0.006$ & $3.017 \pm 0.02$ & $14.77 \pm 0.31$ \\
\hline $\mathrm{P} 22$ & $12.667 \pm 0.003$ & $26.393 \pm 0.0001$ & $150 \pm 0.004$ & $4.788 \pm 0.03$ & $19.90 \pm 0.08$ \\
\hline $\mathrm{P} 23$ & $14.629 \pm 0.0002$ & $30.853 \pm 0.0002$ & $138 \pm 0.001$ & $1.745 \pm 0.02$ & $14.82 \pm 0.17$ \\
\hline $\mathrm{P} 24$ & $5.405 \pm 0.0001$ & $11.130 \pm 0.0002$ & $121 \pm 0.002$ & $2.203 \pm 0.04$ & $25.54 \pm 0.35$ \\
\hline $\mathrm{P} 25$ & $20.027 \pm 0.0004$ & $42.346 \pm 0.0005$ & $128 \pm 0.003$ & $2.896 \pm 0.27$ & $12.98 \pm 0.19$ \\
\hline $\mathrm{P} 26$ & $15.448 \pm 0.0001$ & $32.472 \pm 0.0001$ & $174 \pm 0.005$ & $3.218 \pm 0.21$ & $18.41 \pm 0.20$ \\
\hline $\mathrm{P} 27$ & $19.607 \pm 0.0001$ & $41.179 \pm 0.0001$ & $155 \pm 0.002$ & $3.498 \pm 0.12$ & $20.66 \pm 0.26$ \\
\hline $\mathrm{P} 28$ & $9.718 \pm 0.0001$ & $20.446 \pm 0.0001$ & $112 \pm 0.001$ & $3.132 \pm 0.08$ & $28.80 \pm 0.20$ \\
\hline P29 & $13.355 \pm 0.0001$ & $27.711 \pm 0.0001$ & $117 \pm 0.001$ & $3.650 \pm 0.02$ & $24.49 \pm 0.31$ \\
\hline P30 & $18.728 \pm 0.0001$ & $39.517 \pm 0.0002$ & $88 \pm 0.002$ & $2.591 \pm 0.05$ & $19.46 \pm 0.19$ \\
\hline P31 & $19.815 \pm 0.0001$ & $41.006 \pm 0.0002$ & $87 \pm 0.003$ & $2.063 \pm 0.07$ & $14.54 \pm 0.02$ \\
\hline P32 & $18.967 \pm 0.0001$ & $39.858 \pm 0.0001$ & $255 \pm 0.008$ & $4.208 \pm 0.05$ & $19.77 \pm 0.10$ \\
\hline P33 & $18.647 \pm 0.0002$ & $39.471 \pm 0.0001$ & $195 \pm 0.001$ & $4.373 \pm 0.03$ & $14.28 \pm 0.19$ \\
\hline P34 & $12.372 \pm 0.0001$ & $25.969 \pm 0.0001$ & $95 \pm 0.002$ & $1.541 \pm 0.03$ & $12.40 \pm 0.54$ \\
\hline P35 & $5.344 \pm 0.0001$ & $10.510 \pm 0.0001$ & $141 \pm 0.001$ & $1.933 \pm 0.05$ & $6.17 \pm 0.06$ \\
\hline P36 & $4.689 \pm 0.0001$ & $10.180 \pm 0.0004$ & $117 \pm 0.001$ & $3.070 \pm 0.05$ & $9.03 \pm 0.09$ \\
\hline P37 & $12.271 \pm 0.0001$ & $25.537 \pm 0.0001$ & $169 \pm 0.001$ & $3.203 \pm 0.03$ & $10.80 \pm 0.19$ \\
\hline P38 & $10.879 \pm 0.0002$ & $22.852 \pm 0.0003$ & $209 \pm 0.002$ & $4.972 \pm 0.03$ & $13.29 \pm 0.17$ \\
\hline P39 & $19.968 \pm 0.0002$ & $42.445 \pm 0.0002$ & $90 \pm 0.002$ & $2.343 \pm 0.05$ & $14.55 \pm 0.18$ \\
\hline $\mathrm{P} 40$ & $18.521 \pm 0.0001$ & $38.874 \pm 0.0002$ & $93 \pm 0.001$ & $2.677 \pm 0.15$ & $17.06 \pm 0.36$ \\
\hline $\mathrm{P} 41$ & $11.046 \pm 0.0001$ & $23.311 \pm 0.0001$ & $170 \pm 0.002$ & $4.437 \pm 0.05$ & $18.30 \pm 0.11$ \\
\hline $\mathrm{P} 42$ & $20.204 \pm 0.0001$ & $42.128 \pm 0.0002$ & $113 \pm 0.001$ & $3.308 \pm 0.03$ & $23.07 \pm 0.15$ \\
\hline $\mathrm{F}$ & 1495.36 & 2769.63 & 217.50 & 412.62 & 754.62 \\
\hline Sig. & 0.002 & 0.002 & 0.002 & 0.002 & 0.001 \\
\hline
\end{tabular}

SC: Sample code

The observed variations in $\beta$-carotene and lycopene are in agreement with the results of several other studies. For example, Fraps et al. (1937) stated that there is an important relationship between the carotene content of the feed and their vitamin-A potency. In addition, they found that five samples of peanut hay varying with $5.6-26.5 \mathrm{mg}$ of carotene per $\mathrm{g}$ had an average value of 1.3 ShermanMunsell units (1.5 international units) per mg of carotene. Muthusamy et al. (2014) reported that there is a strong relationship between the $\beta$-carotene and vitamin-A concentrations in cereals and that this relationship can be improved using genetic manipulations. They determined that, while in the original plant, the $\beta$-carotene content was $1.9-2.6 \mu \mathrm{g} / \mathrm{g}$, in an improved maize kernel, the $\beta$-carotene level was 10-21 $\mu \mathrm{g} / \mathrm{g}$. Peanut seeds are the third most important source of free amino acids (Lusas, 1979; Newell et al., 1967). It has been proposed that the protein and amino acids in peanuts have a preventive effect for malnutrition and that the nutritive value of peanut protein is considerably better than that of other plant cultivars (Conkerton and Ory, 1976; Pelto and Armar-Klemesu, 2011). The variation in the total free amino acid content depends significantly on the cultivar. In our study, the lowest levels of free amino acids varied between $5.69 \mu \mathrm{g} / \mathrm{g}$ and $9.03 \mu \mathrm{g} / \mathrm{g}$, the moderate levels varied between 10.80 $\mu \mathrm{g} / \mathrm{g}$ and $19.94 \mu \mathrm{g} / \mathrm{g}$ and the highest levels varied between $2066 \mu \mathrm{g} / \mathrm{g}$ and $28.80 \mu \mathrm{g} / \mathrm{g}$ (Table 2). The lowest free amino acid content was detected in $\mathrm{P} 3$, while the highest content was found in P28 (Table 2). These results are similar to those of many other investigators. Wang et al. (2013) 
investigated the protein and amino acid contents of peanuts using 141 genotypes collected from 12 provinces in China. Their results revealed that the protein values were $6.53 \mathrm{mg}$. The level of free amino acids ranged from 2.36 to $3.00 \mu \mathrm{g}$, threonine and leucine had the highest values but glycine (2.36) $\mu \mathrm{g}$ and serine (2.40) $\mu \mathrm{g}$ had the lowest values. Sanders et al. (1996) examined the biochemical compositions of peanut seed collected from six locations and found glutamic acid and phenylalanine to be the major amino acids with content ranging from $18.5 \mu \mathrm{mol} / \mathrm{g}$ to 37.2 $\mu \mathrm{mol} / \mathrm{g}$. Kabelova et al. (2009) estimated the concentrations of 16 free amino acid in 25 kinds of cheese. In the investigated cheeses, the total free amino acid levels varied between $27 \mathrm{~g} / \mathrm{kg}$ and $160 \mathrm{~g} / \mathrm{kg}$. Leucine, lysine, and phenylalanine (bitter tasting amino acids), proline and valine (bittersweet amino acids) and glutamic acid and aspartic acid (salty-umami amino acids) dominated the cheeses. Andersen et al. (1998) studied peanut cultivars to determine the relationship between fatty acid and amino acid profiles. They found that glutamine/glutamic acid and asparagine/aspartic acid accounted for $36-40 \%$ of total amino acids and that sulphur-containing acid, such as cysteine, methionine, threonine, and lysine, had the lowest levels. In addition, Solanki and Sarangi (2014) pointed out that environmental conditions such as drought affect the levels of the free amino acid content and that tolerant genotypes have more amino acids, e.g. $6.124 \mathrm{mg} / \mathrm{g}$, while susceptible cultivars have less amino acid, e.g. $4.261 \mathrm{mg} / \mathrm{g}$. secondary compounds, such as phenolic acids, tannins and flavonoids, synthesised by plants are known nonenzymatic antioxidants (Pratt and Hudson, 1990). Due to their antioxidant properties, they may increase a plant's defence system by scavenging reactive oxygen species (ROS) damage (Jia et al., 1999). In addition, they contribute to maintaining the nutritional quality and shelf life of foods, as well as preventing diseases such as cardiovascular diseases, anticarcinogenic and antiallergenic activities by inhibiting ROS accumulation (Sales and Resurreccion, 2009; Hathoor et al., 2012). The amount of total phenols in the 42 peanut cultivars varied between $1.75 \mu \mathrm{g} / \mathrm{g}$ and $7.737 \mu \mathrm{g} / \mathrm{g}$ phenols belonged to the $23^{\text {rd }}$ sample but the highest phenol level was found in P9 (Table 2). The total flavonoid content of the 42 samples was between $87 \mu \mathrm{g} / \mathrm{g}$ and $255 \mu \mathrm{g} / \mathrm{g}, 208 \mu \mathrm{g} / \mathrm{g}$ and $198 \mu \mathrm{g} / \mathrm{g}$, respectively (Table 2). Data of the phenols were similar to those detected for different legume member genotypes by Samshuddin et al. (2015). They studied 40 locally consumed foodstuffs to reveal their TPCs. Their results showed the amount of TPC was lowest in green peas (Pisum sativum) as $0.38 \mathrm{mg}$ but was the highest in curry leaves (Murraya koenigi) as $18.40 \mathrm{mg}$. Hathor et al. (2012) found that the antioxidant capacity and flavour of peanut paste and peanut butter were enhanced by peanut skins. Their data revealed that the initial TPCs were $158 \mathrm{mg}, 12.9$ $\mathrm{mg}$ and $14.1 \mathrm{mg}$ in peanut paste and peanut butter, respectively. Sebeia et al. (2013) analysed the total phenolic levels in peanut seed cultivars. They found that the highest total phenols were observed in Chounfakhi as $2.1 \mathrm{mg}$, in Massriya and Sinya cultivars as $1.35 \mathrm{mg}$ and in Trabilsia as $1 \mathrm{mg}$. Khaopha et al. (2012) compared the amount of total phenols in peanuts, including coated and coat-removed seeds, and their findings showed that the phenolic contents were $2.47-84.53 \mathrm{mg}$ and $0.07-0.12 \mathrm{mg}$, respectively. In addition, the predominant phenolic acid in the coat was p-hydroxybenzoic acid; however, in all the coat-removed seeds, the p-coumaric acid levels were higher than those of the other identified phenolic acids. Duh and Yen (1997) stated that total phenols might vary depending on the solvent type. They found that the total phenols per g peanut hull were $41.8 \mathrm{mg}, 19.9 \mathrm{mg}$ an $7.3 \mathrm{mg}$ of methanol, ethanol and acetone solvents, respectively. The results of the total flavonoids were consistent with those of other studies. Kuang et al. (2017) compared the chemical compositions of red and black peanut cultivars with seed coats and cotyledon. Their results indicated that the seed coat had higher saponin and anthocyanin levels. In addition, the saponin content varied between $0.02 \mathrm{mg} / \mathrm{g}$ and $20.53 \mathrm{mg} / \mathrm{g}$. Ren et al. (2012) analysed 10 varieties of legume seeds to determine their total flavonoid contents. They found that the amount of flavonoid varied between $0.30 \mathrm{mg}$ and $3.38 \mathrm{mg}$ and that rice beans, kidney beans and lentils had the highest flavones of the analysed legumes. According to the study results of Shem-Tov et al. (2011), peanut seed coats are rich in many antioxidants compounds including total phenols, total flavonoids, and total anthocyanin and these compound are located especially in the seed coats and may change their flavour and colour. Hou et al. (2017) evaluated the total flavonoid contents in 57 peanut seeds. The number of flavones in the seeds was 0.39-4.53 mg RT g ${ }^{-1}$, with 11.6 times higher maximum value than the minimum value. Seeds and other parts of legumes store sugars as glucose, fructose, sucrose, total soluble carbohydrates and insoluble carbohydrates in different amounts (Basha, 1976; Gorecki et al., 2000). These chemicals may increase the resistance of seeds to desiccation during seed maturation and storage, and they protect the cellular structural stability of organelles, membranes, enzymes and other macromolecules (Obendorf et al., 1997; Bewley, 2001). There were no significant differences in our samples $(\mathrm{P}<0.05)$ in terms of the glucose level; however, the fructose and sucrose concentrations showed important differences between the peanut samples (Table 3). The glucose level varied between $0.978 \mu \mathrm{g} /(\mathrm{P} 39)$ and $1.111 \mu \mathrm{g}$ (P9). The amount of fructose and sucrose in the peanut samples was 0.216 $0.784 \mu \mathrm{g}$ (P41-P10) and 1.337-4.644 $\mu \mathrm{g}$ (P36-P15), respectively (Table 3 ). The sugar results were in agreement with other investigations. Patee et al. (2000) investigated the effect of sugars on the sweet attribute. Their result showed that the total soluble carbohydrate ranged from $0.248 \mathrm{mg}$ to $0.917 \mathrm{mg}$, while the glucose ranged from 0.022 to $0.504 \mathrm{mg}$. The fructose level was between 0.020 and $0.520 \mathrm{mg}$; however, the sucrose content ranged from $0.235 \mathrm{mg}$ to $0.927 \mathrm{mg}$. Vercellotti et al. (1995) studied the carbohydrate metabolism changes in peanuts to compare the effects of drying methods and found that the soluble carbohydrates contain primarily inositol, glucose, fructose, sucrose (>80\% total sugars), raffinose and stachyose. They stated that the amount of sugars varies depending on the maturation stage with the environmental conditions and that the sugars provide precursors to the compounds that influence the flavor and characteristics of peanuts. However, the sugar contents may change in correlation to seed size, the pre/post harvesting conditions and the storage time (Basha et al., 1976; Pattee et al., 1981). 
Table 3 Changing of Glucose, fructose and saccharose content in peanut cultivars.

\begin{tabular}{l|ccc}
\hline SC & $\begin{array}{c}\text { Glucose } \\
\mu \mathrm{g} / \mathrm{g}\end{array}$ & $\begin{array}{c}\text { Fructose } \\
\mu \mathrm{g} / \mathrm{g}\end{array}$ & $\begin{array}{c}\text { Saccharose } \\
\mu \mathrm{g} / \mathrm{g}\end{array}$ \\
\hline P1 & $0.991 \pm 0.066$ & $0.294 \pm 0.004$ & $2.222 \pm 0.012$ \\
$\mathrm{P} 2$ & $1.105 \pm 0.008$ & $0.542 \pm 0.002$ & $2.215 \pm 0.010$ \\
$\mathrm{P} 3$ & $1.095 \pm 0.002$ & $0.481 \pm 0.002$ & $3.045 \pm 0.013$ \\
P4 & $1.085 \pm 0.002$ & $0.231 \pm 0.004$ & $3.221 \pm 0.010$ \\
P5 & $1.098 \pm 0.003$ & $0.274 \pm 0.008$ & $3.148 \pm 0.017$ \\
P6 & $1.096 \pm 0.001$ & $0.485 \pm 0.006$ & $2.890 \pm 0.035$ \\
P7 & $1.098 \pm 0.001$ & $0.716 \pm 0.001$ & $2.791 \pm 0.007$ \\
P8 & $1.096 \pm 0.001$ & $0.649 \pm 0.002$ & $2.744 \pm 0.004$ \\
P9 & $1.111 \pm 0.004$ & $0.735 \pm 0.002$ & $3.074 \pm 0.007$ \\
P10 & $1.100 \pm 0.003$ & $0.784 \pm 0.005$ & $2.892 \pm 0.012$ \\
P11 & $1.068 \pm 0.012$ & $0.650 \pm 0.003$ & $2.814 \pm 0.024$ \\
P12 & $1.086 \pm 0.007$ & $0.602 \pm 0.001$ & $2.640 \pm 0.032$ \\
P13 & $1.096 \pm 0.003$ & $0.225 \pm 0.006$ & $2.821 \pm 0.012$ \\
P14 & $1.093 \pm 0.002$ & $0.679 \pm 0.002$ & $2.605 \pm 0.025$ \\
P15 & $1.096 \pm 0.003$ & $0.546 \pm 0.003$ & $4.644 \pm 2.178$ \\
P16 & $1.063 \pm 0.001$ & $0.612 \pm 0.003$ & $2.689 \pm 0.007$ \\
P17 & $1.102 \pm 0.003$ & $0.747 \pm 0.003$ & $2.706 \pm 0.010$ \\
P18 & $1.040 \pm 0.005$ & $0.549 \pm 0.001$ & $2.678 \pm 0.007$ \\
P19 & $1.050 \pm 0.003$ & $0.742 \pm 0.005$ & $2.701 \pm 0.095$ \\
P20 & $1.082 \pm 0.003$ & $0.632 \pm 0.002$ & $2.946 \pm 0.036$ \\
P21 & $1.062 \pm 0.008$ & $0.567 \pm 0.015$ & $2.892 \pm 0.025$ \\
P22 & $1.066 \pm 0.006$ & $0.656 \pm 0.004$ & $2.701 \pm 0.110$ \\
P23 & $1.098 \pm 0.003$ & $0.607 \pm 0.002$ & $3.230 \pm 0.009$ \\
P24 & $0.998 \pm 0.004$ & $0.692 \pm 0.025$ & $1.575 \pm 0.010$ \\
P25 & $1.061 \pm 0.005$ & $0.676 \pm 0.012$ & $2.179 \pm 0.019$ \\
P26 & $1.067 \pm 0.005$ & $0.635 \pm 0.002$ & $2.455 \pm 0.009$ \\
P27 & $1.076 \pm 0.009$ & $0.638 \pm 0.021$ & $2.932 \pm 0.006$ \\
P28 & $1.067 \pm 0.008$ & $0.345 \pm 0.003$ & $3.261 \pm 0.013$ \\
P29 & $1.063 \pm 0.001$ & $0.533 \pm 0.002$ & $2.454 \pm 0.008$ \\
P30 & $0.990 \pm 0.004$ & $0.450 \pm 0.002$ & $2.500 \pm 0.013$ \\
P31 & $1.054 \pm 0.003$ & $0.520 \pm 0.002$ & $2.155 \pm 0.021$ \\
P32 & $1.070 \pm 0.007$ & $0.543 \pm 0.003$ & $2.258 \pm 0.016$ \\
P33 & $1.060 \pm 0.010$ & $0.220 \pm 0.003$ & $2.719 \pm 0.005$ \\
P34 & $1.056 \pm 0.001$ & $0.275 \pm 0.004$ & $2.750 \pm 0.041$ \\
P35 & $1.086 \pm 0.006$ & $0.347 \pm 0.003$ & $2.427 \pm 0.005$ \\
P36 & $1.082 \pm 0.002$ & $0.533 \pm 0.003$ & $1.337 \pm 0.009$ \\
P37 & $1.094 \pm 0.006$ & $0.279 \pm 0.002$ & $2.704 \pm 0.017$ \\
P38 & $1.048 \pm 0.009$ & $0.612 \pm 0.002$ & $2.947 \pm 0.007$ \\
P39 & $0.978 \pm 0.047$ & $0.519 \pm 0.002$ & $3.041 \pm 0.013$ \\
P40 & $1.084 \pm 0.015$ & $0.468 \pm 0.002$ & $2.885 \pm 0.011$ \\
SC:S & $1.056 \pm 0.001$ & $0.216 \pm 0.002$ & $2.679 \pm 0.023$ \\
P & $1.061 \pm 0.001$ & $0.358 \pm 0.002$ & $3.324 \pm 0.011$ \\
\hline
\end{tabular}

SC: Sample code

It has been reported that the amounts and types of carbohydrates changed in pea embryos during maturation and in mature embryos (Goreck et al., 2000). Gorska Koplinska et al. (2010) found that mature pea embryos had higher sucrose levels $(84.494 \mu \mathrm{g})$ as well as lower amounts of fructose $(0.053 \mu \mathrm{g})$ and glucose $(0.197 \mu \mathrm{g})$. The total soluble carbohydrates content was the highest at 369-130 $\mu \mathrm{g}$ at maturation. Promchote et al. (2009) studied two peanut cultivars to determine the relationship between seed composition and the physiological changes to maturation. The authors observed that the size of the seed, the weight, and the seed/hull dry-weight were highest when the seed was mature. The amounts of carbohydrate and protein contents in seeds of Kaset 1 were $55.9 \%$ and in seeds of Tainan 9 were $54.8 \%$ at this stage. In addition, they determined that, while the oil content increased before maturation, the carbohydrate content decreased. However, at maturity, the oil and carbohydrate level of both cultivars varied depending on the seed size.

The results from the present study revealed that the investigated peanut samples showed significant nutritional potential depending on their location. There were significant differences linked to $\beta$-carotene, lycopene, total free amino acid, total phenolic, flavonoid, glucose, fructose, and sucrose content $(\mathrm{P}<0.05)$ between the peanut samples. As a result, a sample of 42 peanuts can be consumed as food or snacks due to their high nutritional value.

\section{References}

Akova Y. 2000. Kuru ve Sert Kabuklu Meyveler D1ş Pazar Araştırması, T.C. Başbakanlık Dış Ticaret Müsteşarlığ İhracatı Geliştirme Etüt Merkezi.

Andersen PC, Hill K, Gorbet DW, Brodbeck BV. 1998. Fatty acid and amino acid profiles of selected peanut cultivars and breeding lines, Journal of Food Composition and Analysis. 11: 100-111.

Arıolu H, Kurt C, Baka H, Onat B, Gulluoğlu L Sinan NS. 2013. The Effect Of Pix Aplied At Different Growing Stages On Some Agronomical Characteristic Peanut. Turkish Journal of Field Crops. 18(2): 260-267.

Basha SMM, Cherry JP, Young CT. 1976. Changes in free amino acids, carbohydrates, and proteins of maturing seeds from various peanut (Arachis hypogaea L.) cultivars. Cereal Chem. 53 (4):586-597.

Bewley JD. 2001. Seed Germination and Reserve Mobilization. J Derek Bewley, University of Guelph, Guelph, Ontario, Canada. Encyclopedia of Life Sciences \& 2001 Nature Publishing Group / www.els.net.

Çalışkan S, Çalışkan ME, Arslan M, Arıŏlu H. 2008. Effects of Sowing Date and Growth Duration on Growth and Yield of Groundnut in a Mediterranean-type Environment in Turkey. Field Crops Research. 105(1-2):131-140.

Chukwumah Y, Walker LT, Verghese M. 2009. Peanut skin color: a biomarker for total polyphenolic content and antioxidative capacities of peanut cultivars. Int. J. Mol. Sci. 10:4941-4952.

Conkerton EJ, Ory RL. 1976. Peanut Proteins as Food Supplements: A Compositional Study of Selected Vir-ginia and Spanish peanut.

Duh PD, Yen GC. 1997. Antioxidant Efficacy of Methanolic Extracts of Peanut Hull in Soybean and Peanut. Oil. J. Am. Oil Chem. Soc. 74: 745-748.

FAO, 2016. İnternet sitesi. http://faostat.fao.org/.

Food and agriculture Organızation Of The United Nations. 2010. Annual report. http://faostat.fao.org/default.aspx (accessed January 10, 2010).

Francisco M, Resurreccion A. 2008. Functional components in peanuts. Crit. Rev. Food Sci. 48:715-746.

Fraps GS, Treichler R, Kemmerer AR.1936. Relation Of The Carotene Content Of Certain Feed Materials To Their Vitamın A Potency. Journal oj Agricultural Research voi. 53 (9):713-716.

Góreck1 RJ, Lahuta LB, Jones AD, Hedley CL. 2000. Soluble sugars in maturing pea seeds of different lines in relation to desiccation tolerance. [In:] Seed Biology. Advences and applications, Eds. M. Black, K.J. Bradford, J. VasquezRamos, 67-74.

Górska-Koplińska K, A Źróbek-Sokolnik A, Górecki RJ, Lahuta L. 2010. Comparison Of Soluble Sugar Accumulation In Zygotic And Somatıc Pea Embryos. Pol. J. Natur. Sc. 25(4): 313-322. 
Gulluoğlu L, Bakal H, Onat B, Arioglu H. 2016. Characterization of peanut (Arachis hypogaea L.) seed oil and fatty acids composition under Mediterranean environmen. Journal of Exğerimental Biology an Agricultur al Sciences. 4(5S):564-571.

Hammond AC, Padgett LJ, Williams MJ. 1992. Relative feeding value of Rhizoma perennial peanut hay as a supplement to bahiagrass hay for wintering beef cows and heifers. Prof. Anim. Sci. 8:48-54.

Hathor CS, Sanders TH. 2012. Flavor and antioxidant capacity of peanut paste and peanut butter supplemented with peanut skins. J Food Sci. 77(11):407-411.

Hou M, Mu G, Zhang Y, Cui S, Yang X, Liu L. 2017. Evaluation of total flavonoid content and analysis of related EST-SSR in Chinese peanut germplasm. Crop Breeding and Applied Biotechnology.17: 221-227.

İşler N, Gözüyeşil R. 2016. Osmaniye İlinde Yerfıstığı Yetiştiriciliği ile İlgili Sorunların Saptanması. Tarla Bitkileri Merkez Araştırma Enstitusu Dergisi. 25 (S-2):36-41.

Jia Z, Tang M, Wu J. 1999. The determination of flavonoids content in mulberry and scavenging effect on superoxide radicals. Food Chemistry. 64:555-599.

Kabelova I, Dvořakova M, Čižkova H, Dostalek P, Melzoch K. 2009. Determination of free amino acids in cheeses from the Czech market. Czech J. Food Sci. 27: 143-150.

Kadiroglu A. 2008. Yerfistığı (Arachis hypogaea L.) yetiştiriciliği”, Batı Akdeniz Tarımsal Araştırma Enstitüsü Müdeürlügü Ya., s.53, Antalya.

Khaopha S, Senawog T, Jogloy S, Patanothia A. 2012. Comparison of total phenolic content and composition Ofindivudal phenolic acids in testae-removed kernels of 15 Valencia-type peanut ((Arachis hypogaea L.) genotypes. Afican Journal of Biotechnology. 11(92):15923-159.

Kuang Q, Yu Y, Attree R, Xu B. 2017. A comparative study on anthocyanin, saponin, and oil profiles of black and red seed coat peanut (Arachis hypogacea) grown in China, International Journal of Food Properties. 20 (1):131-140.

Kumaran A, Karunakaran RJ. 2006. Antioxidant and free radical scavenging activity of an aqueous extract of Coleus aromaticus. Food Chem. 97:109-114.

Landrum JT. 2010. Carotenoids: Physical, Chemical, and Biological Functions and Properties. CRC Press; Boca Raton, FL, USA.

Li L, Yuan H. 2013. Chromoplast biogenesis and carotenoid accumulation. Arch.Biochem.Biophys. 539:102-109.

Lusas EW. 1979. Food uses of peanut protein. Jam Oil Chem Soc. 56:425-530.

Moise AR, Al-Babili S, Wurtzel ET. 2013. Mechanistic aspects of carotenoid biosynthesis. Chem.Rev. 114: 164-193.

Moore S., Stein WH. 1948. Photometric method for use in chromatography of amino acids. J. Biol. Chem. 176:367-388.

Muthusamy V, Hossain F, Thirunavukkarasu N, Choudhary M, Saha S, Bhat JS. 2014. Development of $\beta$-Carotene rich maize hybrids through marker-assisted introgression of $\beta$-carotene hydroxylase allele. PLoS ONE 9:e113583.

Nagata M, Yamashita I.1992. Simple method for simultaneous determination of chlorophyll and carotenoids in tomato fruit. Nippon Shokuhin Kogyo Gakkaish. 39:925-928.

Nepote V, Grosso NR, Guzman CA. 2005. Optimization of extraction of phenolic antioxidants from peanut skins. J. Sci. Food Agric. 85:33-38.

Newell JA, Mason ME, Matlock RS. 1967. Precursors of typical and a typical roasted peanut flavor. J. Agric. Food Chem. 15(5):767-772.

Obendorf RL, Dickerman AM, Pflum TM, Kacalanos MA, Smith ME. 1998. Drying rate alterssoluble carbohydrates, desiccation tolerance, and subsequent seedling growth of soybean (Glycinemax L. Merrill) zygotic embryos during in vitro maturation. Plant Science. 132: 1-12.

Pattee HE, Isleib TG, Giesbrecht FG, McFeeters RF. 2000. Investigations into genotypic variations of peanut carbohydrates. Jourrnal Agric Food Cham. 48:750-756.
Pattee HE, Young CT, Giesbrecht FG. 1981. Seed size and storage effects on carbohydrates of peanuts. J. Agric. Food Chem. 29, 800.

Pearson D, Melon HK, Ronald S. 1976. Chemical Analysis of Food. 8th edition. Churchill Livingstone, pp. 5-63.

Pelto GH, Armar-Klemesu M. 2011. Balancing Nurtur-ance, Cost and Time: Complementary Feeding in Accra, Ghana. Maternal \& Child Nutrition. 7(3):66-81.

Pratt DE, Hodson BJF. 1990. Natural antioxidants not exploited cemmercially. First. Ed. In: Hudson BJF., editor. Food Antioxidants. Elsevier, Armsterdam. P:171.

Promchote P, Duangpatra J, Chanprasert W. 2008. Seed Composition and Physiological Changes in Thai Peanut cv. Kaset 1 and Tainan 9 during Maturation. Kasetsart J. (Nat. Sci.). 42(3): 407-416.

Ren SC, Liu ZL, Wang P. 2012. Proximate composition and flavonoids content and in vitro antioxidant activity of 10 varieties of legume seeds grown in China. Journal of Medicinal Plants Research. 6 (2): 301-308.

Sales JM, Resurreccion AVA. 2010. Phenolic profile, antioxidants, and sensory acceptance of bioactive-enhanced peanuts using ultrasound and UV. Food Chemistry. 122: 795803.

Samshuddin S, Kamath SD, Avinash NG, Arunkamar D. 2015. Determination of total phenolic content and total antioxidant activity in locally consumed food stuffs in Moodbidri, Karnataka, India. Adv. Appl. Sci. Res. 6(6):99-102.

Sanders TH, Grimm DT, Pattee HE, Williams DE, SanchezDominguez S. 1996. Chemical Composition of Arachis hypogaea L. Subsp. hypogaea Var. hirsuta Peanuts. Peanut Science. 23(2):111-116.

Sanders TH, Vercellotti JR, Blankenship PD, Crippen KL, Civille GV. 1989. Interaction of maturity and curing temperature on descriptive flavor of peanuts. J. Food Sei. 54:1066-1069.

Sebeia K, Gnoumaa A, Herchia W, Sakouhia F, Boukhchinaa S. 2013. Lipids, proteins, phenolic composition, antioxidant and antibacterial activities of seeds of peanuts (Arachis hypogaea 1) cultivated in Tunisia. Biol Res. 46: 257-263.

Shem-Tov Y, Galili S, Badanı H, Segey A, Hedvat I, Hovav R. 2011. Determination of Total Polyphenol, Flavonoid and Anthocyanin contents and Antioxidants Capacities of skins from Peanut (Arachis hypogea L.) Lines with differet skin colors. Journal of Food Biochemistry. 36:301-308.

Singleton VL. Orthofer R, Lamuela-Raventos RM. 1999. Analysis of total phenols and other oxidation substrates and antioxidants by means of Folin-Ciocalteu reagent. Methods Enzymol. 299:152-178.

Solanki KJ, Sarangi SK. 2014. Effect of drought stress on proline accumulation in peanut genotypes. International Journal of Advanced Research. 2(10):301-309.

Usda National Nutrient Database For Standard Reference. 2010. Nutrient data laboratory. http://www.nal.usda.gov/fnic /foodcomp/search (accessed February 25, 2009).

Vercellotti JR, Sanders TH, Chung SY, Bete KL, Vinyard BT. 1995. Carbohydrate metabolism in peanuts during postharvest curing and maturation. G. Charalambous (Ed.), Food Flavors: Generation, Analysis and Process Influence. 1547-1578.

Wang L, Wang Q, Liu H, Lu L, Du Y. 2013. Determining the contents of protein and amino acids in peanuts using nearinfrared reflectance spectroscopy. Sci Food Agric. 93: 118124.

Xu BJ, Yuan SH, Chang SKC. 2007. Comparative analyses of phenolic composition, antioxidant capacity, and color of cool season legumes and other selected food legumes. J.Food Sci. 72: 167-177.

Young CT, Matlock RS, Mason RE, Waller GR. 1974. Effect of harvest date and maturity upon free amino acid levels in three varieties of peanut. J. Amer. Oil Chem. SOC. 51(6):269-273 